\title{
Pharmacognostical and Phytochemical Screening of the Root of Martynia Annua Linn
}

\author{
D.O.I - 10.51201/Jusst12568 \\ http://doi.org/10.51201/Jusst12568 \\ Dr Rahul Kumar Gupta*, Dr Renu Bharat Rathi*** \\ *PhD Scholar, MGACH\&RC, Wardha(H), Maharashtra, India. \\ ** Professor, Department of Kaumarbhritya, MGACH\&RC, Wardha (H), Maharashtra, India.
}

\begin{abstract}
Background : for acceptance of Ayurveda at global level there is needed to standardize herbal drugs according to modern techniques. For the standardization of herbal medicines it is essential to establish its identify, purity, quality, safety, and efficacy. This study reports on standardization of Martina annua linn root. In tribal pockets of satpura plateau in Madhya Pradesh. Root paste of Martina annua is used in folk medicine to treat cancer and rheumatism.
\end{abstract}

Objective: This study aimed to indentify anthers herb and establishing pharmacognostical, Physiochemical and phytochemical standard for the Martina annua linn. Root.

\section{Material and Methods:}

Plant roots was collected from Govt. Ayurved college campus, Gwalior, Madhya Pradesh and evaluated for pharmacognostical, Physiochemical and phytochemical parameter using guidelines of the world health organization and pharmacopoeial laboratory for Indian medicine for quality control of herbal drugs.

Results: Chemical evaluation shown presence of alkaloids, glycosides, flavonoids, steroids and tannins. The microscopic characters have shown presence of Epiblema, Periderm, Cortex, Phloem and Madullary Rays, and Xylem vessels. Microscopy analysis of the powder included the parenchyma cells, fibers and vessel.

In results, it was found that the root containing various phytochemicals were present in its

Aqueous extract, Hydroalcoholic extract and Alcoholic extract. Hydroalcoholic extract of Martynia annua root had the highest of total phenolic content (364.15 $\mathrm{mg} \mathrm{GAE} \mathrm{/100gm)} \mathrm{and} \mathrm{highest} \mathrm{total} \mathrm{flavonoid}$ content (139.84 mg QE /100gm).

Conclusions: Pharmacognostical and preliminary phytochemical screening of Martynia annua roots will be useful in order to authenticate, standardize and avoid any adulteration in the raw material and will be helpful in the development of a monograph.

Keywords: Martynia annua, Pharmacognosy, Phytochemistry.

\section{INTRODUCTION}

Herbal medicine is the oldest and commonly clinical practices in the world today. The knowledge of Indian medicinal plants and their uses in the Indian system of medicine have led to many Scientific Investigations and Researches throughout the world. The systematic phytochemical screening not only support in informative the active components but also support in the synthesis of better and newer analogues and congeners of different active principles isolated from plants.[1] These studies help in correct identification and authentication of the plant material. Correct identification and quality assurance 
of the herbs is an essential prerequisite to ensure reproducible quality of herbal medicine which will contribute to its safety and efficacy.[2]

Martynia annua L. belongs to Family Martyniaceae commonly known as "bichu”(Figure 1)

Martynia annua is commonly found in dense cluster on roadsides, degraded moist and dry deciduous forest, waste lands and over-grazed pasture. It is a weedy foreign species native to tropical and sub-tropical region of Mexico, Central America, Burma, West Pakistan and naturalized throughout India. Its excellent dispersal mechanism has helped it spread throughout the tropical world as a weed.[3]

In folklore practices decoction of whole plant is given in pneumonia and cold fever. The poultice of roots used in snake bite for external application. Roots of Martynia annua are boiled in milk and taken as a tonic in folklore. In Tribal Pockets of Satpura Plateau in Madhya Pradesh, Root paste of Martynia annua is used to treat Cancer and rheumatism.[4]

In current era recent advances has identified various test and parameters to determine the quality control of drugs.[5] The present study aim was the macroscopic and microscopic characterstics of Root of the plant and analyzes Physico-chemical and Preliminary phytochemical properties of the various extracts of Martynia annua root.

\section{MATERIALS AND METHODS}

\section{Chemicals}

Folin-Ciocalteu phenol reagent, gallic acid, quercetin, anhydrous sodium carbonate, methanol, deionized water, chloroform, benzene, petroleum ether, ethanol, sodium nitrite, aluminum trichloride, sodium hydroxide, and all other chemical of laboratory grade were used.

\section{Plant Material}

The plant was collected from Govt. Ayurved College Campus, Gwalior (Madhyapradesh) during the month of January 2018. Preserved this plant as herbarium in departmental repository and was authenticated from Regional Ayurveda Research Institute for Metabolic Disorders (RARI) Bangalore (Karnataka). Its authentication number is Authentication/SMPU/RARIMD /BNG/2017-18, Bengaluru, Dated 26/02/2018.

\section{Macroscopic Evaluation}

The size, color, surface characteristics, texture, fracture characteristics and odor of the roots were studied using standard methods.[6]

\section{MICROSCOPIC EVALUATION}

The intact root and root powder were studied under a microscope to analyze the cellular characteristics of the drug.

\section{Qualitative microscopy}

\section{(a) Study of transverse section:-}

The roots were taken in a test tube and $5 \% \mathrm{KOH}$ in methanol was added so that the sample remained submerged. The samples were boiled over Bunsen burner for few minutes. A transverse section of the root was taken in a watch glass containing water with the help of a brush. The sections were then transferred to a watch glass containing phloroglucinol-hydrochloric acid (1:1) and allowed to stain for 2-3 minutes. The Root sections were again transferred to watch glasses containing $\mathrm{H}_{2} \mathrm{O}$, so as the excess stain was washed away. The root sections were then placed on clean glass micro-slides, with the support of a brush. Few drops of $\mathrm{H}_{2} \mathrm{O}$ were added, and a clean cover-slip was placed on the slide. The slides were Kept for study on the microscope.

\section{(b) Study of powder characteristics:-}

The collected root was washed with distilled $\mathrm{H}_{2} \mathrm{O}$ to remove the dust and adhering materials and then was dried under shade. The shade-dried root was powdered by means of mechanical grinder and the powder was allowed to pass through sieve no. 80 for powder microscopy. The root powder was boiled with chloral hydrate to remove the colouring matters, mounted on the glass slides 
using glycerin and covered with a cover slip and examined under Leica DM 1000 microscope. The representative images of sections were taken with the support of Digital Olympus microscope.[7]

\section{Physicochemical evaluation:-}

The various physicochemical parameters such as Loss on Drying at $110^{\circ} \mathrm{C}$, total ash, acid insoluble ash, water insoluble ash, alcohol soluble extractives, water soluble extractive, ether soluble extractives value and $\mathrm{pH}(10 \%$ solution w/v) content were determined.[8], [9]

\section{Qualitative phytochemical evaluation of different Extracts of Martynia annua Root} Extraction

The coarse powder of shade-dried plant were successively extracted in soxhlet extractor using the solvents such as alcohol (ethanol), water:ethanol (50:50) and distill water. All three root extracts obtained were concentrated and dried under vacuum.

\section{Qualitative Phytochemical screening}

All plant extracts were subjected to chemical tests for the presence of phytochemical classes like Carbohydrate, Protein, Alkaloid, Cardiac glycoside, Flavonoids, Tannins, Antraquinone, glycoside, Steroids and Triterpenoides using standard procedure.[8], [10]

\section{Fluorescence analysis}

All plant extracts were treated with acids such as $10 \% \mathrm{HCL}$ and $10 \% \mathrm{H}_{2} \mathrm{SO} 4$; and alkaline solutions such as sodium hydroxide, $\mathrm{MeOH}$; and other solvents such as $10 \% \mathrm{NH} 3$ and $10 \% \mathrm{HNO}$. They were subjected to fluorescence analysis in daylight and in the ultraviolet (UV)-light (254 nm) using standard methods.[11]

\section{Thin layer chromatographic studies}

TLC is mentioned as a primary tool for identification as part of monographs on all medicinal plants.[12] All plant extracts were subjected to thin layer chromatographic studies using reported methods to determine the presence of various phyto-constituents.[13]

The results were compared with the results obtained in the qualitative tests. The mobile phases and detecting reagents of different classes of compounds were used.

\section{Determination of total Phenolic contents:}

The amount of total phenolics in extracts was studied with the Folin-Ciocalteu reagent. Gallic acid was used as a standard and the total phenolics were mentioned as $\mathrm{mg} / \mathrm{g}$ gallic acid equivalents (GAE). Concentration of $0.01 \mathrm{mg} / \mathrm{ml}, 0.02 \mathrm{mg} / \mathrm{ml}, 0.03 \mathrm{mg} / \mathrm{ml}, 0.04 \mathrm{mg} / \mathrm{ml}$ and $0.05 \mathrm{mg} / \mathrm{ml}$ of gallic acid were prepared in methanol.

Concentration of $0.1 \mathrm{mg} / \mathrm{ml}$ and $1 \mathrm{mg} / \mathrm{ml}$ of plant extract were also prepared in methanol and $0.5 \mathrm{ml}$ of each sample were introduced into test tubes and mixed with $2.5 \mathrm{ml}$ of a 10 fold dilute FolinCiocalteu reagent and $2 \mathrm{ml}$ of $7.5 \% \mathrm{Na}_{2} \mathrm{CO}_{3}$. The tubes were secured with parafilm and permitted to stand for half hour at room temperature before the absorbance was read at $760 \mathrm{~nm}$ spectrometrically. All screening was performed in triplicate. The Folin-Ciocalteu reagent being sensitive to reducing compounds including polyphenols is producing a blue color upon reaction which is measured spectrophotometrically.[14]

\section{Determination of total flavonoids content:}

The total flavonoids content of each plant extract was determined by method described by Zhishen et al.[15] Based on this method, each sample (1.0ml) was mixed with $4 \mathrm{ml}$ of distilled water and subsequently with $0.30 \mathrm{ml}$ of a $\mathrm{NaNO} 2$ solution $(10 \%)$. After $5 \mathrm{~min}, 0.30 \mathrm{ml} \mathrm{AlCl} 3$ solution (10\%) was added followed by $2.0 \mathrm{ml}$ of $\mathrm{NaOH}$ solution (1\%) to the mixture. Immediately, the mixture was thoroughly mixed and absorbance was then studied at $510 \mathrm{~nm}$ versus the blank. Standard curve of quercetin was prepared $(0-12 \mathrm{mg} / \mathrm{ml})$ and the results were expressed as quercetin equivalents $(\mathrm{mg}$ quercetin/gm dried extract). 


\section{RESULTS}

\section{Macroscopic Evaluation}

All the organoleptic features studied have been tabulated in Table 1.

\section{Microscopic Evaluation}

(a) Study of transverse section:-

In transverse section, roots are characterized by the presence of thick brownish continuous eight to ten layers of parenchyma cells. Outer zone contain epiblema layer, and inner zone consist of cortex layer. The phloem was presence of oval shape, thick walled cells of lignified parenchymatous sheath. Collapsed phloem is formed beneath of cortex layer. Medullary rays and xylem vessels also found in T.S. (Figure 2).

\section{Study of powder characteristics:-}

Powder analysis of Martynia апnиа root observed that polygonal cells of parenchyma, fragment of vessel with pitted wall in surface view, bunches of fibers with yellow thick mass of tissues along with mesh-like structure.

Study shows the presence of the parenchyma cells, fibers, tracheid and spiral vessels.

The fiber length was also determined and found to be $50 \mu \mathrm{m}$. This value can be used as an identifying characteristic for Martynia annua roots (Figure 3).

\section{Physicochemical Properties of Martynia annua}

The ash values namely total ash, acid-insoluble ash and water-soluble ash; extractive values, namely alcohol-soluble extractive value, water-soluble extractive, and Ether-soluble extractive values; LOD and $\mathrm{pH}$ were calculated and recorded. Results are tabulated in Table 3.

\section{Preliminary Phytochemical Screening}

The qualitative phytochemical evaluation by chemical tests of all the extracts obtained after successive extraction showed the presence of Carbohydrate, Protein, Alkaloid, Cardiac glycoside, Flavonoids, Tannins, Antraquinone glycoside, Steroids and Triterpenoides. Result is tabulated in Table 4.

Fluorescence analysis of Martynia annua L. roots extract:

The various root extracts were examined under day light and UV light to find out the presence of fluorescence compound within them and result are summarized in Table 5.

\section{Thin layer chromatographic studies:}

All the root extracts of Martynia annua were subjected to thin layer chromatography by using Chloroform: Methanol (9: 1) and Toluene: Ethyl acetate: Diethylamine (70:20:10) solvent system respectively and Spraying Agent were Iodine and Dragendorff's reagent respectively.

The resulting both TLC pattern was viewed under long wave ultraviolet light at $366 \mathrm{~nm}$ or Short wave ultraviolet light at $254 \mathrm{~nm}$. Results of TLC 1 and TLC 2 before and after derivatization are summarized in Table 6 and Table 7 respectively.

Determination of total Phenolic and total flavonoids contents: The different extracts were also examined for determination of total Phenolic and total flavonoids contents and results are tabulated in Table 8.

\section{DISCUSSION}

The root of Martynia annua belonging to the family Martyniaceae is a widely growing plant throughout India. The plant also has many valuable medicinal properties. Our literature review revealed that so far no works has been done on the root of Martynia annua. Hence, this study deals with the pharmacognostical identification and phytochemical screening of the this plant.

The morphological studies of roots of Martynia апnиa showed the shape of the root is more or less cylindrical, slightly tapering. Colour of the peeled root is pale yellow while an unpeeled root is yellowish brown to dark brown with a rough surface. The macroscopic as well as microscopic studies of Martynia 
annua root revealed that by using their diagnostic features can be identify this plant root very easily for further investigations.

The proximate analysis revealed that Loss on drying of Martynia annua roots powder was found to be $5.8 \%$. Percentages of total ash, water insoluble ash and acid insoluble ash were found to be 10.5 , 8.05 and $3.48 \%$, respectively. These values are useful to recognize the sample of authentic drug.

Fluorescence study is used for identification only on the basis of colour (fluorescence compound) found during study we can able to identify Martynia annua Root in a mixture or compound.

TLC profiling of all three extracts gives an impressive result that directing towards the presence of number of phytochemical. Different phytochemicals gives various Rf values in various solvent systems. These Rf estimations of the photochemical gives a very important idea in understanding of their polarity and also supports in selection of suitable solvent system for separation of pure compounds by column chromatography. Mixture of solvents with variable polarity in various proportions can be used for separation of pure compound from plant extract. The selection of suitable solvent system for a particular plant extracts can only be achieved by analyzing the $\mathrm{R}_{\mathrm{f}}$ estimations of compounds in various solvent system.

The TLC method is best choice for the identification of secondary metabolite exist in plants.

In Fig.4 (TLC 1) before derivatization 4 spots seen at $\mathrm{R}_{\mathrm{f}} 0.07,0.13,0.28 \& 0.43$ and these are common in all three extracts while other spots are absent in aqueous extract. Spot seen at $R_{f} 0.20$ present only in alcohlic extract that shows compound present at $R_{f} 0.20$ is soluble in alcohol only and other spots are found common in Hydroalcohlic and alcohlic extract. After derivatization 5 spots seen at $\mathrm{R}_{\mathrm{f}} 0.07$, $0.13,0.20,0.28 \& 0.43$ and these are common in all three extracts while other spots $\left(\mathrm{R}_{\mathrm{f}} 0.51,0.63,0.73\right.$, $0.90,0.96$ ) are absent in aqueous extract. All spots found in Hydroalcohlic and alcohlic extract are common.

In Fig.4 (TLC 2) before derivatization one spot seen at $\mathrm{R}_{\mathrm{f}} 0.05$ and that is common in all three extracts while other spots $\left(\mathrm{R}_{\mathrm{f}} 0.03,0.08,0.14,0.21,0.35,0.490 .64,0.76 \& 0.87\right)$ are absent in aqueous extract. All 10 spots found in Hydroalcohlic and alcohlic extract are common. After derivatization one spot seen at $R_{f} 0.05$ and that is common in all three extracts while other spots are absent in aqueous extract. all 12 spots found in Hydroalcohlic and alcohlic extract are common.

Here the various $R_{f}$ values indicate the presence of different nature of phytoconstituents in single extracts. $\mathrm{R}_{\mathrm{f}}$ values of the compound also gives an idea about their polarity. This information will support in selection of suitable solvent system for further separation of compound from these plant extracts.

Standard curve used for the determination of total phenolic and flavonoids content were prepared using various concentrations of Gallic acid equivalent (GAE) and quercetin and their respective optical density as shown in figure 5 and 6 respectively. The concentration of these compounds in different extracts is shown in table 7.

Total phenolic content is significantly high in Hydro-alcoholic extract $364.15 \mathrm{mg} \mathrm{GAE} / 100 \mathrm{gm}$ of extract. Similarly significant high concentrations of total flavonoids (139.84 mg QE/100gm extract) have been observed in Hydro-alcoholic extract as compared other extracts.

Flavonoids are the most diverse and widespread group of natural compounds are probably the most important natural phenols. These compounds show a broad spectrum of chemical and biological activities including radical scavenging properties.

\section{CONCLUSIONS}

The present study gives an account on the preliminary pharmacognostic and phytochemical screening of Martynia annua roots which may useful in order to authenticate, standardize and avoid any adulteration. The diagnostic microscopical characters and physicochemical data reported in this study will be helpful in the development of a monograph. TLC studies help to verify adulteration in quality control of crude extract. Further due to the presence of various phytoconstituents appeared to be the potential to act as a source of useful drugs and also to inhance the health status of the consumers as a result of the presence of various phytoconstituents that are vital role for good health. With this, it was also found high 
contents of phenolic and flavonoid compounds, indicating that these compounds contribute to the antioxidant activity.

Table 1. Organoleptic features of Martynia annua roots.

\begin{tabular}{|c|c|}
\hline Features & Observations \\
\hline Shape & Cylindrical \\
\hline Width & $1-5 \mathrm{~cm}$ Length $20-50 \mathrm{~cm}$ \\
\hline Color & $\begin{array}{c}\text { Peeled-pale yellow, unpeeled yellowish brown to dark } \\
\text { brown. }\end{array}$ \\
\hline Odour & Faint and characteristic \\
\hline Taste & Characteristic, free from bitterness. \\
\hline
\end{tabular}

Table 2. Organoleptic characters of Root Powder of Martynia annua

\begin{tabular}{|l|c|c|}
\hline 1. & Colour & Greyish-green \\
\hline 2. & Odour & Characteristic \\
\hline 3. & Taste & Bitter, acrid, slightly sweet \\
\hline 4. & Touch & Mealy and fibrous \\
\hline
\end{tabular}

Table 3: Physicochemical properties of Root Powder of Martynia anna

\begin{tabular}{|c|c|}
\hline Parameters & Values in \% \\
\hline \multicolumn{2}{|c|}{ Ash value } \\
\hline Total Ash value & \multicolumn{2}{|c|}{} \\
\hline Acid-insoluble ash value & $30.50 \%$ \\
\hline Water-soluble ash value & $3.48 \%$ \\
\hline \multicolumn{2}{|c|}{ Extractive value } \\
\hline Alcohol-soluble extractive value & $5.05 \%$ \\
\hline Water-soluble extractive value & $32.65 \%$ \\
\hline Ether-soluble extractive value & $6.45 \%$ \\
\hline Loss on drying at $110^{\circ} \mathrm{C}$ & $5.80 \%$ \\
\hline pH (10\% solution $\mathrm{w} / \mathrm{v})$ & $6.62+0.10$ \\
\hline
\end{tabular}

Table 4 Preliminary phytochemical screening of various root extracts of Martynia anna

\begin{tabular}{|c|c|c|c|}
\hline Constituents & $\begin{array}{c}\text { Aqueous } \\
\text { extract }\end{array}$ & $\begin{array}{c}\text { Hydroalcoholic } \\
\text { extract }\end{array}$ & Alcoholic extract \\
\hline Carbohydrate & Present & Present & Present \\
\hline Protein & Present & Present & Absent \\
\hline Alkaloid & Absent & Present & Present \\
\hline Cardiac glycoside & Present & Present & Present \\
\hline Flavonoids & Present & Present & Present \\
\hline Tannins & Present & Present & Present \\
\hline Antraquinone glycoside & Present & Present & Present \\
\hline Steroids & Present & Present & Present \\
\hline Triterpenoides & Present & Present & Present \\
\hline
\end{tabular}


Table 5

Fluorescence characteristics of different extracts of root of Martynia anna

\begin{tabular}{|c|c|c|}
\hline Aqueous Extract & Color in visible light & Color in long UV \\
\hline Sample + water & Faded yellow & Fluorescent green \\
\hline Sample $+\mathrm{MeOH}$ & Straw & Fluorescent yellow \\
\hline Sample $+10 \% \mathrm{NaOH}$ & Light orange & $\begin{array}{l}\text { Light fluorescent orange } \\
\text { yellow }\end{array}$ \\
\hline Sample $+10 \% \mathrm{HCl}$ & Transparent & Green \\
\hline Sample $+10 \%$ HNO3 & Pale yellow & Fluorescent pale green \\
\hline Sample $+10 \%$ H2SO 4 & $\begin{array}{c}\text { Transparent with yellow } \\
\text { tinge }\end{array}$ & Light fluorescent green \\
\hline Sample + 10\% NH3 & Light brownish yellow & Bright fluorescent cream \\
\hline $\begin{array}{c}\text { Hydro-alcoholic } \\
\text { Extract }\end{array}$ & Color in visible light & Color in long UV \\
\hline Sample + water & Light yellow & Fluorescent greenish-yellow \\
\hline Sample + MeOH & Orange-yellow & Bright fluorescent cream \\
\hline Sample $+10 \% \mathrm{NaOH}$ & Light reddish-brown & Fluorescent green \\
\hline Sample $+10 \% \mathrm{HCl}$ & Pale yellow & Fluorescent greenish-yellow \\
\hline Sample + 10\% HNO3 & Light yellow & Fluorescent greenish-yellow \\
\hline Sample $+10 \% \mathrm{H} 2 \mathrm{SO} 4$ & $\begin{array}{c}\text { Transparent with yellow } \\
\text { tinge }\end{array}$ & Light fluorescent yellow \\
\hline Sample + 10\% NH3 & Light yellowish-orange & Yellowish cream \\
\hline Alcoholic Extract & Color in visible light & Color in long UV \\
\hline Sample + water & Light yellow & Fluorescent green \\
\hline Sample + MeOH & Light orange-yellow & Fluorescent greenish-yellow \\
\hline Sample $+10 \% \mathrm{NaOH}$ & Brownish-yellow & Fluorescent orange \\
\hline Sample $+10 \% \mathrm{HCl}$ & Creamish-green & Fluorescent greenish-yellow \\
\hline Sample + 10\% HNO3 & Light creamish-green & Fluorescent greenish-yellow \\
\hline Sample + 10\% H2SO4 & Creamish-green & Fluorescent greenish-yellow \\
\hline Sample + 10\% NH3 & Light red wine & Bright fluorescent yellow \\
\hline
\end{tabular}


Table 6

Thin Layer Chromatography of various extracts of root of Martynia annua

TLC-1

Solvent System: Chloroform: Methanol:: 9: 1Spraying Agent: Iodine Rf values of solutes separated from the various extracts of root of Martynia annua

\begin{tabular}{|c|c|c|c|}
\hline \multicolumn{4}{|c|}{ Under Long UV Before Spray } \\
\hline $\begin{array}{c}\text { Rf } \\
\text { Values }\end{array}$ & Aqueous extract & $\begin{array}{c}\text { Hydro-alcoholic } \\
\text { extract }\end{array}$ & Alcoholic extract \\
\hline 0.07 & Lemon yellow & Lemon yellow & Lemon yellow \\
\hline 0.13 & Fluorescent blue & Fluorescent blue & Fluorescent blue \\
\hline 0.20 & --- & --- & Fluorescent green \\
\hline 0.28 & $\begin{array}{c}\text { Light fluorescent } \\
\text { blue }\end{array}$ & Light fluorescent blue & $\begin{array}{c}\text { Light fluorescent } \\
\text { blue }\end{array}$ \\
\hline 0.43 & $\begin{array}{c}\text { Light fluorescent } \\
\text { blue }\end{array}$ & Light fluorescent blue & $\begin{array}{c}\text { Light fluorescent } \\
\text { blue }\end{array}$ \\
\hline 0.51 & --- & Light fluorescent blue & $\begin{array}{c}\text { Light fluorescent } \\
\text { blue }\end{array}$ \\
\hline 0.63 & --- & Light fluorescent blue & $\begin{array}{c}\text { Light fluorescent } \\
\text { blue }\end{array}$ \\
\hline 0.73 & --- & Fluorescent blue & Fluorescent blue \\
\hline 0.90 & --- & Fluorescent cream & Fluorescent cream \\
\hline 0.96 & --- & Fluorescent cream & Fluorescent cream \\
\hline
\end{tabular}

\begin{tabular}{|c|c|c|c|}
\hline \multicolumn{4}{|c|}{ Under Long UV After Spray } \\
\hline $\begin{array}{c}\mathbf{R}_{\mathbf{f}} \\
\text { Values }\end{array}$ & Aqueous extract & $\begin{array}{c}\text { Hydro-alcoholic } \\
\text { extract }\end{array}$ & Alcoholic extract \\
\hline 0.07 & Lemon yellow & Lemon yellow & Lemon yellow \\
\hline 0.13 & Lemon yellow & Lemon yellow & Lemon yellow \\
\hline 0.17 & --- & Lemon yellow & Lemon yellow \\
\hline 0.20 & $\begin{array}{c}\text { Light fluorescent } \\
\text { blue }\end{array}$ & Light fluorescent blue & $\begin{array}{c}\text { Light fluorescent } \\
\text { blue }\end{array}$ \\
\hline 0.28 & $\begin{array}{c}\text { Light fluorescent } \\
\text { blue }\end{array}$ & Light fluorescent blue & $\begin{array}{c}\text { Light fluorescent } \\
\text { blue }\end{array}$ \\
\hline 0.43 & $\begin{array}{c}\text { Light fluorescent } \\
\text { blue }\end{array}$ & Light fluorescent blue & $\begin{array}{c}\text { Light fluorescent } \\
\text { blue }\end{array}$ \\
\hline 0.51 & --- & $\begin{array}{c}\text { Light fluorescent } \\
\text { cream }\end{array}$ & $\begin{array}{c}\text { Light fluorescent } \\
\text { cream }\end{array}$ \\
\hline 0.63 & --- & $\begin{array}{c}\text { Light fluorescent } \\
\text { cream }\end{array}$ & $\begin{array}{c}\text { Light fluorescent } \\
\text { cream }\end{array}$ \\
\hline 0.73 & --- & Fluorescent cream & Fluorescent cream \\
\hline 0.90 & --- & Fluorescent cream & Fluorescent cream \\
\hline 0.96 & Fluorescent cream & Fluorescent cream \\
\hline
\end{tabular}


Table 7

TLC- 2

Dragendorff's reagent

Solvent System: Toluene: Ethyl acetate: Diethylamine: 70:20:10 Spraying Agent:

Rf values of solutes separated from the various extracts of root of Martynia annua

\begin{tabular}{|c|c|c|c|}
\hline \multicolumn{5}{|c|}{ Under Long UV Before Spray } \\
\hline Rf Values & Aqueous extract & $\begin{array}{c}\text { Hydro-alcoholic } \\
\text { extract }\end{array}$ & Alcoholic extract \\
\hline 0.03 & --- & Fluorescent green & Fluorescent green \\
\hline 0.05 & Fluorescent blue & Fluorescent blue & Fluorescent blue \\
\hline 0.08 & --- & Light brown & Light brown \\
\hline 0.14 & --- & Light fluorescent blue & Light fluorescent blue \\
\hline 0.21 & --- & Fluorescent cream & Fluorescent cream \\
\hline 0.35 & --- & Light fluorescent blue & Light fluorescent blue \\
\hline 0.49 & --- & Light brown & Brown \\
\hline 0.64 & --- & Fluorescent blue & Fluorescent blue \\
\hline 0.76 & --- & Fluorescent blue & Fluorescent blue \\
\hline 0.87 & --- & Fluorescent blue & Fluorescent blue \\
\hline & & Under Long UV After Spray \\
\hline Rf Values & Aqueous extract & Hydro-alcoholic & extract \\
\hline 0.03 & --- & Fluorescent green & Alcoholic extract \\
\hline 0.05 & Fluorescent green & Fluorescent cream & Fluorescent green \\
\hline 0.08 & --- & Light brown & Light brown \\
\hline 0.14 & --- & Fluorescent blue & Fluorescent blue \\
\hline 0.21 & --- & Fluorescent cream & Fluorescent cream \\
\hline 0.35 & --- & Light brown & Light brown \\
\hline 0.43 & --- & Light reddish-brown & Reddish-brown \\
\hline 0.53 & --- & Light fluorescent cream & Light fluorescent cream \\
\hline 0.64 & --- & Light fluorescent cream & Light fluorescent cream \\
\hline 0.71 & --- & Reddish-brown & Reddish-brown \\
\hline 0.76 & --- & Fluorescent blue & Fluorescent blue \\
\hline 0.87 & --- & Fluorescent blue & Fluorescent blue \\
\hline
\end{tabular}

Table 8

Total phenolic and Flavonoid content in different root extracts of Martynia annua

\begin{tabular}{|c|c|c|c|}
\hline Quantitative Estimation & $\begin{array}{l}\text { Aqueous } \\
\text { extract }\end{array}$ & $\begin{array}{l}\text { Hydro-alcoholic } \\
\text { extract }\end{array}$ & $\begin{array}{l}\text { Alcoholic } \\
\text { extract }\end{array}$ \\
\hline $\begin{array}{l}\text { Total phenolic (Gallic acid } \\
\text { equivalent) }\end{array}$ & $\begin{array}{l}232.25 \\
\mathrm{mg} / 100 \mathrm{gm}\end{array}$ & $364.15 \mathrm{mg} / 100 \mathrm{gm}$ & $\begin{array}{l}315.55 \\
\mathrm{mg} / 100 \mathrm{gm}\end{array}$ \\
\hline $\begin{array}{l}\text { Total Flavonoid (Quercetin } \\
\text { equivalent) }\end{array}$ & $82.5 \mathrm{mg} / 100 \mathrm{gm}$ & $139.84 \mathrm{mg} / 100 \mathrm{gm}$ & $\begin{array}{l}118.36 \\
\mathrm{mg} / 100 \mathrm{gm}\end{array}$ \\
\hline
\end{tabular}




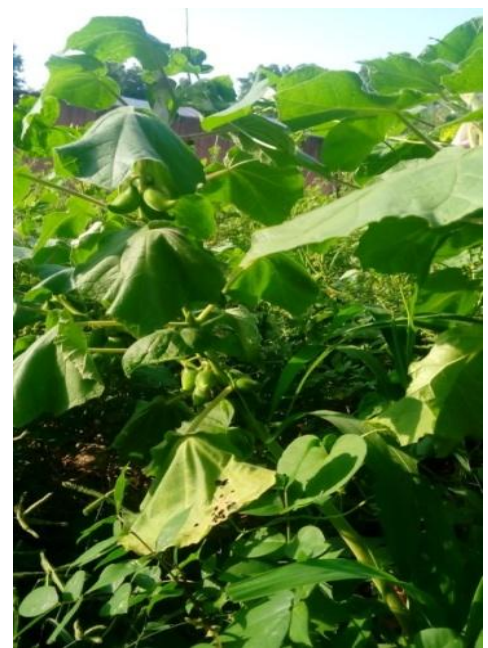

Fig.1. (a). Martynia annua Linn.(plant)

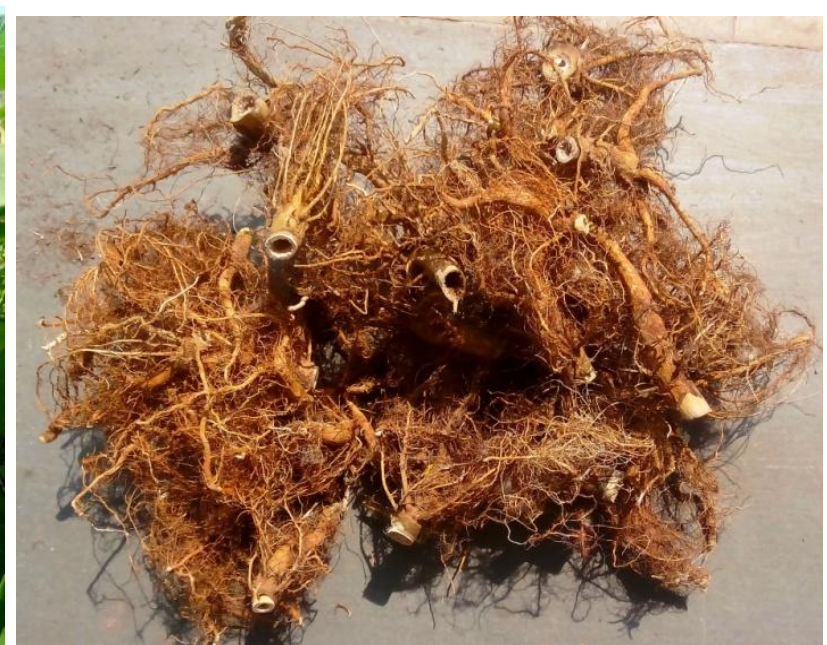

(b). Root of Martynia annua



(A). outline of T.S.,

(C). periderm in L.S.

Fig.2. Transverse section of Martynia annua Root 
Powder Characters

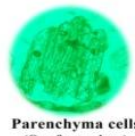

Parenchyma cells
(Surface view)
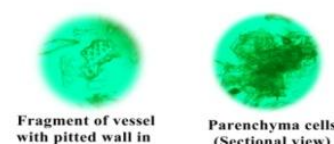

Parenchyma cells
(Sectional view)

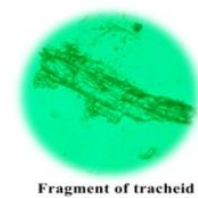

ragment of tracheid
(Surface view)



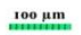
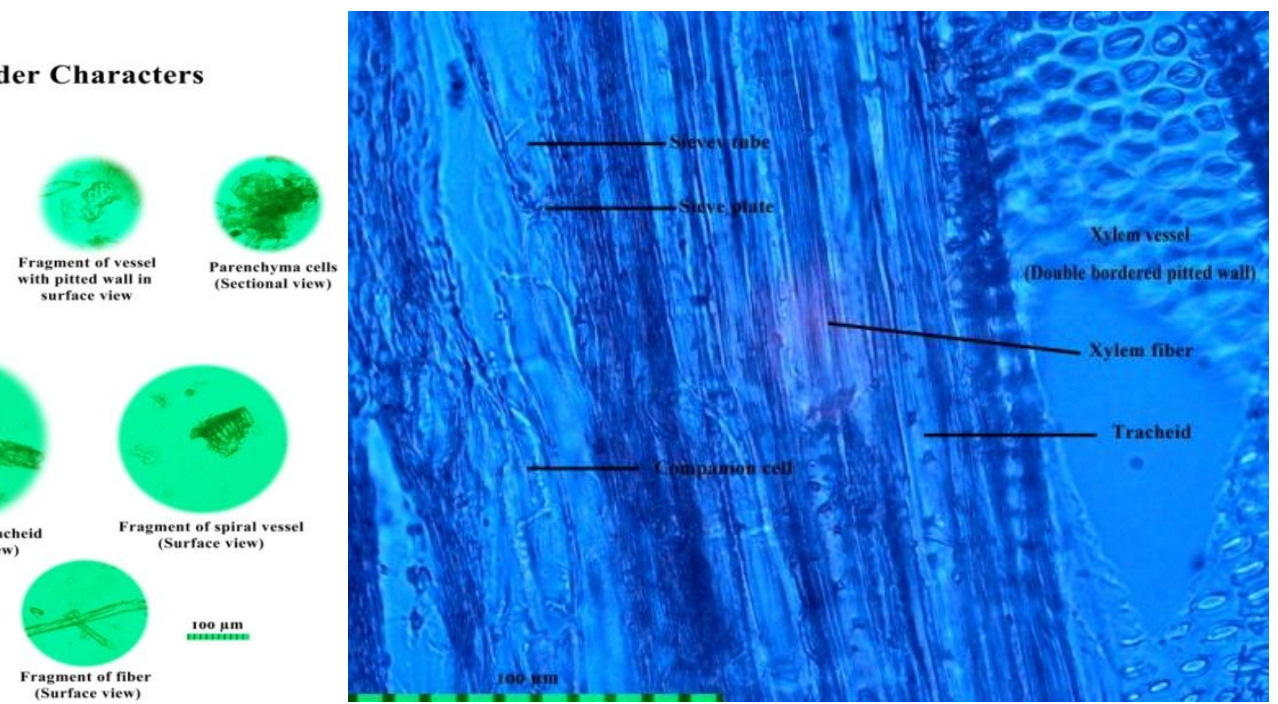

(B). Xylem and Phloem in L.S.

(A). Powder characters

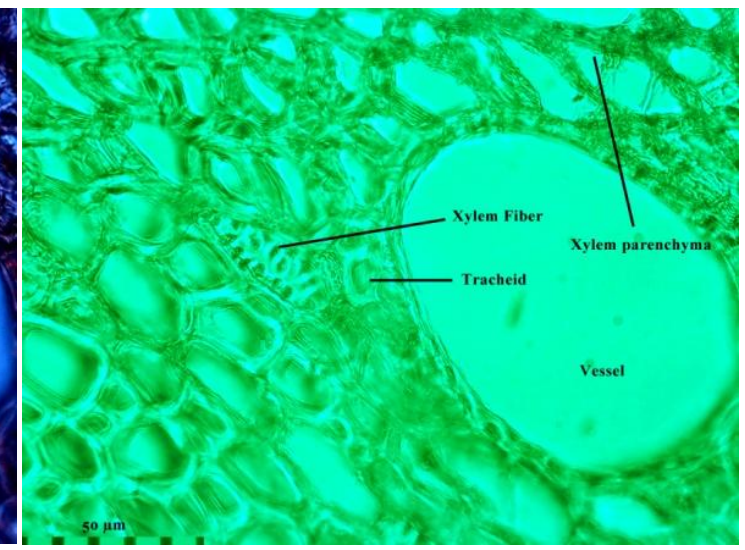

(D). Xylem Elements

(C). Xylem Elements(UV)

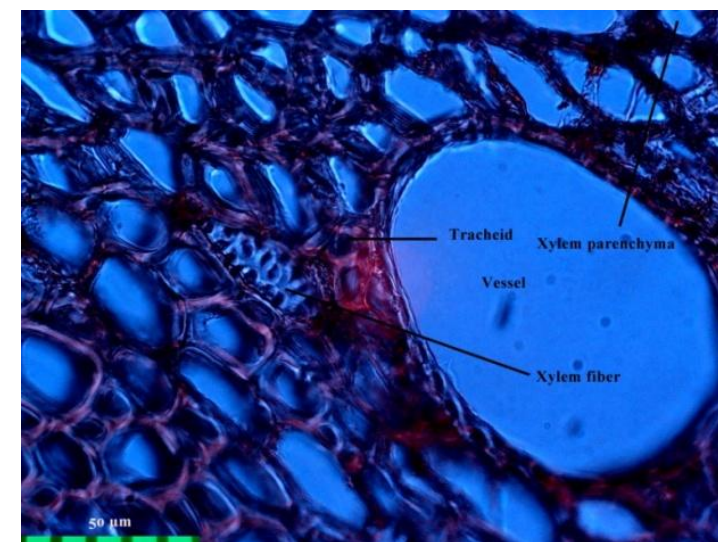

Fig.3. Microscopic characters of Martynia annua Root powder

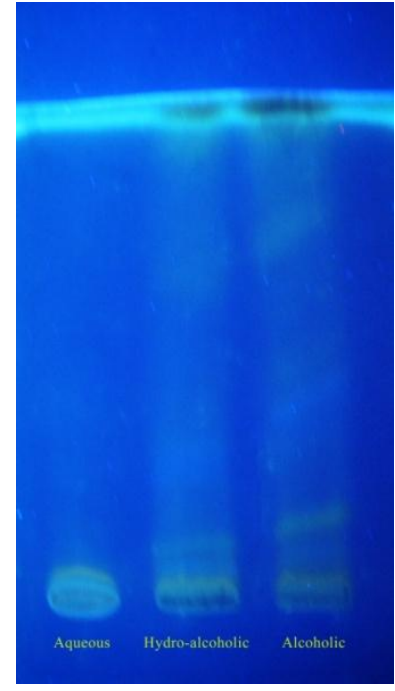

Before derivatization Under Long UV After derivatization Under Long UV

TLC-1

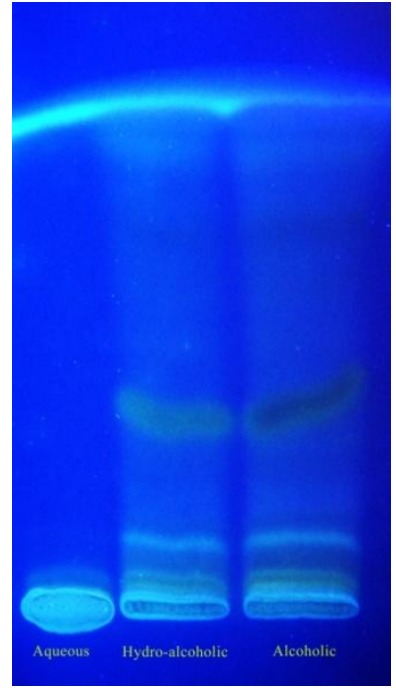

Before derivatization Under Long UV

$$
\text { TLC-2 }
$$

Fig.4. TLC of Aqueous, Hydroalcoholic and alcoholic exracts of Martynia annua Root 


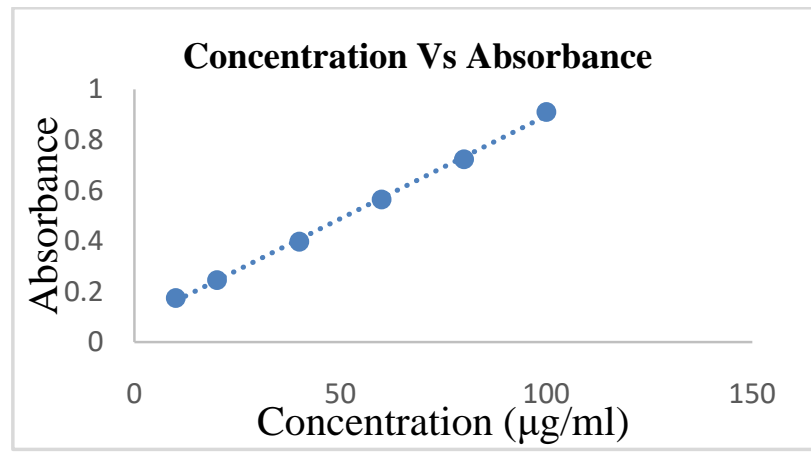

Fig.5, Standard curve of different concentrations $(\mathrm{mg} / \mathrm{ml})$ of gallic acid and their respective optical density (OD) at $760 \mathrm{~nm}$.

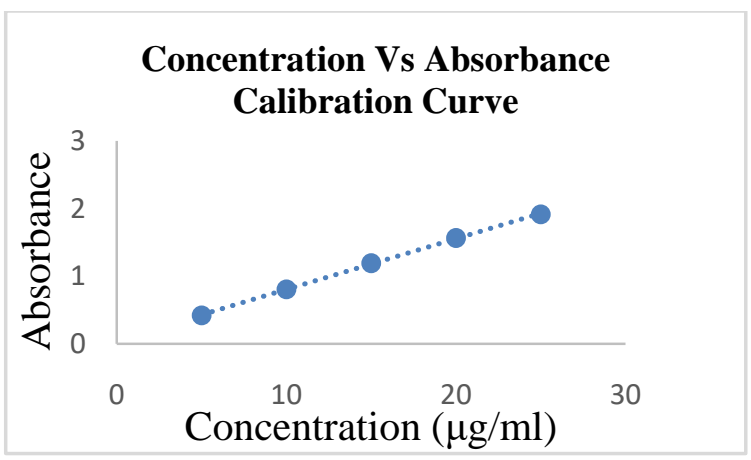

Fig.6, Standard curve of different concentrations $(\mathrm{mg} / \mathrm{ml}) \quad$ of Quercetin and their respective optical density (OD) at 510nm.

\section{REFERENCES}

[1] K. Vivekanand, "PHYTOCHEMICAL AND PHARMACOGNOSTICAL STUDIES OF MARTYNIA ANNUA PLANT,” p. 5, 2012.

[2] D. Kaushik, M. K. Pandey, and A. Sharma, "Current issues in Authentication and Quality control of Natural Products,” Res. Plant Biol., p. 8, 2014.

[3] "http://www.backyardnature.net/q/martynia.htm Sierra Gorda Biosphere Reserve, QUERÉTARO, MÉXICO September 14, 2007." [Online]. Available: http://www.backyardnature.net/q/martynia.htm. [Accessed: 15-Apr-2018].

[4] R. Gupta and M. Deogade, A Critical Review on Martynia annua Linn, vol. 9. 2018.

[5] M. Deogade, A. Wanjari, and S. C Lohakare, Pharmacognostical and Phytochemical study of Costus igneus NE Br leaf Original Article, vol. 2. 2014.

[6] D. Kumar, K. Kumar, S. Kumar, T. Kumar, A. Kumar, and O. Prakash, "Pharmacognostic evaluation of leaf and root bark of Holoptelea integrifolia Roxb., " Asian Pac. J. Trop. Biomed., vol. 2, no. 3, pp. 169-175, Mar. 2012.

[7] M. Patel and C. R. Harisha, "Macroscopic, microscopic, and micrometric evaluation of Madhavilata (Hiptage benghalensis Linn. (Kurz.) flower, ”p. 5.

[8] "Kokate CK. Practical Pharmacognosy. 4th ed. New Delhi: Vallabh Prakashan; 2003. p. 122-6.," .

[9] "Ministry of Health and Family Welfare. Indian Pharmacopoeia. 4th ed., Vol. 2. New Delhi: The Controller of Publications, Ministry of Health and Family Welfare, Government of India; 1996. p. A53-4.," .

[10] "Harborne JB. Phytochemical Methods. A Guide to Modern Techniques of Plant Analysis. 3rd ed. New York: Chapman and Hall Int. Ed.; 1998.,". 
[11] C. R. Chase and R. Pratt, "Fluorescence of powdered vegetable drugs with particular reference to development of a system of identification,"

J. Am. Pharm. Assoc. Am. Pharm. Assoc., vol. 38, no. 6, pp. 324-331, Jun. 1949.

[12] "Eike Reichetal, TLC for the Analysis of Herbal Drugs-A Critical Review of the Status and Proposal for Improvement of Monographs,ScientificNote,Pharmeuropa 15.3, July 2003, 424-430.," .

[13] Stahl E, Ashworth MRF. Thin-layer chromatography. Springer; 1969. .

[14] M. Sultana, P. K. Verma, R. Raina, S. Prawez, and M. A. Dar, "Quantitative Analysis of Total Phenolic, Flavonoids and Tannin Contents in Acetone and n-hexane Extracts of Ageratum conyzoides, " p. 4.

[15] "Zhishen, J., Mengcheng, T., Jianming, W. (1999), The determination of flavonoid contents in mulberry and their scavenging effects on superoxide radicals. Food Chemistry. 64(4), Page No. 555-559.," . 